\title{
Biological redundancy of endogenous GPCR ligands in the gut and the potential for endogenous functional selectivity
}

\author{
Georgina L. Thompson ${ }^{1}$, Meritxell Canals ${ }^{1}$ and Daniel P. Poole ${ }^{1,2}$ * \\ ' Drug Discovery Biology, Monash Institute of Pharmaceutical Sciences, Parkville, VIC, Australia \\ 2 Department of Anatomy and Neuroscience, The University of Melbourne, Parkville, VIC, Australia
}

\section{Edited by:}

Dominique Massotte, Institut des

Neurosciences Cellulaires et

Intégratives, France

Reviewed by:

Jakub Fichna, Medical University of Lodz, Poland

Pamela J. Hornby, Johnson \&

Johnson, USA

\section{*Correspondence:}

Daniel P. Poole, Drug Discovery

Biology, Monash Institute of

Pharmaceutical Sciences, 381 Royal

Parade, Parkville, VIC 3052, Australia

e-mail: daniel.poole@monash.edu
This review focuses on the existence and function of multiple endogenous agonists of the somatostatin and opioid receptors with an emphasis on their expression in the gastrointestinal tract. These agonists generally arise from the proteolytic cleavage of prepropeptides during peptide maturation or from degradation of peptides by extracellular or intracellular endopeptidases. In other examples, endogenous peptide agonists for the same $\mathrm{G}$ protein-coupled receptors can be products of distinct genes but contain high sequence homology. This apparent biological redundancy has recently been challenged by the realization that different ligands may engender distinct receptor conformations linked to different intracellular signaling profiles and, as such the existence of distinct ligands may underlie mechanisms to finely tune physiological responses. We propose that further characterization of signaling pathways activated by these endogenous ligands will provide invaluable insight into the mechanisms governing biased agonism. Moreover, these ligands may prove useful in the design of novel therapeutic tools to target distinct signaling pathways, thereby favoring desirable effects and limiting detrimental on-target effects. Finally we will discuss the limitations of this area of research and we will highlight the difficulties that need to be addressed when examining endogenous bias in tissues and in animals.

Keywords: biased agonism, enteric nervous system, G protein-coupled receptor, somatostatin, somatostatin receptor, opioid, opioid receptor

\section{ENDOGENOUS BIASED AGONISM}

The last decade has witnessed the experimental confirmation of previous theoretical concepts demonstrating that GPCRs exist in many temporally related micro-conformations (Deupi and Kobilka, 2010). Mechanistically, this inherent plasticity is in line with recent biophysical studies indicating that GPCRs can adopt multiple active states that can be differentially stabilized by chemically distinct classes of ligands (Hofmann et al., 2009; Bokoch et al., 2010). Such plasticity allows GPCRs to mediate a spectrum of acute signaling and longer-term regulatory behaviors that can be activated in a ligand-specific manner. Indeed, it is now established that different agonists do not uniformly activate all cellular signaling pathways linked to a given receptor. Rather, different ligands binding to the same receptor stabilize distinct receptor conformations linked to different signaling pathways and physiological outcomes. This paradigm whereby different ligands, binding to the same GPCR in an identical cellular background, promote distinct receptor conformational states linked to a different functional outcome has been termed biased agonism or functional selectivity. Therapeutically, biased agonism provides new avenues for the development of drugs that are not only receptor-specific but also 'pathway-specific.' As such it has opened the field to the discovery of ligands that selectively activate signaling pathways mediating desired physiological effects whilst minimizing 'on-target' sideeffects that are elicited by activation of other signaling pathways via the same receptor.
To date, most descriptions of biased agonism have focused on the differential effects of synthetic drugs. However, there are several functionally important GPCR families that bind to multiple endogenous agonists [for example chemokine, somatostatin (SST), and opioid receptors (ORs)]. Although this has been traditionally attributed to the redundancy of some biological systems, biased agonism could represent an added layer of control to engender finely tuned physiological responses. Indeed, recent reports have already highlighted the potential for functional selectivity across the chemokine receptor family (Rajagopal et al., 2013; Zweemer et al., 2014).

In this focused review we provide an overview of the existing literature regarding two of these GPCR families with multiple endogenous peptide ligands, opioids and SST, in the context of the gastrointestinal tract (GIT). The opioid system is a prototypical example of potential biological redundancy, and it also represents one of the first examples where functional selectivity of synthetic drugs has been reported in the context of gut physiology. On the other hand, SST receptors are therapeutic targets in treating GI disease (e.g., diarrhea, bleeding varices, neuroendocrine tumors) and SSTs and related peptides also represent a well-characterized system where multiple endogenous ligands of the same receptor exist within the GIT (Zhao et al., 2013). Importantly, these two receptor systems also reveal different mechanisms that can explain distinct physiological outcomes derived from activation of the same receptor by different ligands. 


\section{THE SOMATOSTATIN SYSTEM OF THE GUT}

There are five members of the SST receptor family $\left(\mathrm{SSTR}_{1-5}\right)$ and their distribution in the GIT has been recently reviewed (Van Op den Bosch et al., 2009).

Somatostatin, originally known as somatotropin releaseinhibiting factor (SRIF), was first identified and characterized as a cyclic tetradecapeptide (Brazeau et al., 1973). It was predicted that SST-14 was a product of a larger peptide precursor and that other forms with potential biological activity were likely to exist. Indeed, it is now known that SST arises from maturation of preprosomatostatin (PPSST), and that all PPSST derivatives originate from the SST gene. The removal of a 24 amino acid signal sequence forms prosomatostatin (PSST), which is further C-terminally cleaved to form the biologically active peptides SST-14, SST-25, and SST-28 (Bohlen et al., 1980; Esch et al., 1980; Brazeau et al., 1981). SST-28, the longest peptide, was identified and characterized as an $\mathrm{N}$ terminally extended variant of SST-14 (Pradayrol et al., 1978, 1980; Bohlen et al., 1980) and biological conversion of SST-28 to SST-14 was later confirmed (Zingg and Patel, 1983). Other cleavage products arising from PSST processing include PSST(1-32; Schmidt et al., 1985) and PSST(1-64; Bersani et al., 1989), for which little information regarding function and expression is available.

$\mathrm{N}$-terminal cleavage of PSST also occurs, but the resulting peptides do not contain the SST-14 sequence and are therefore not considered to be SSTs (Benoit et al., 1990). These include SST28(1-12) and antrin, which contains amino acids 1-10 of PSST [PPSST(25-34)]. Antrin, first identified in the gastric antrum (Benoit et al., 1987), is present in all SST-producing tissues. However, a functional role for this peptide has yet to be ascribed. Most recently, a bioinformatics approach predicted the existence of a novel 13mer PPSST cleavage product [PPSST(31-43)], which was subsequently confirmed by immunoaffinity purification and called neuronostatin (Samson et al., 2008). Neuronostatin is encoded by PSST and is highly conserved across vertebrates. Unlike SST and cortistatin (CST, see below), neuronostatin is not cyclic and is amidated at the C-terminus.

Biological activity of SST variants is conferred through a common Phe-Trp-Lys-Thr (FWKT) motif within the C-terminus (amino acids 7-10; Patel and Srikant, 1997). This sequence is also present in non-SST peptides that share a high-degree of sequence homology with SST. These include CST and thrittene. CST and SST are encoded by distinct genes, and genetic deletion of SST has no effect on the expression of CST. CST is a derivative of the 112 amino acid preproCST (PPCST) precursor (de Lecea etal., 1996), which is converted to proCST by signal peptide cleavage, resulting in the formation of hCST17 and hCST29 (Puebla etal., 1999). CST shares 11 amino acids in common with SST-14 including residues required for interaction with SSTRs and two key cysteines that enable formation of the cyclic peptide structure (Francis et al., 1990). Although they share sequence homology, structure, and affinity for SSTRs, there are clear differences in the ability of CST and SST-14 to stimulate SSTR2 endocytosis and signaling (Liu et al., 2005). Notably, CST is significantly less effective at inhibiting cAMP production and promoting SSTR2 endocytosis. Furthermore, CST does not exclusively interact with SST receptors and can also activate the MrgX2 and GHS-R1a receptors. Whether there are CST variants or a CST-specific GPCR is unknown. Another endogenous peptide that shares extensive sequence homology with SST is thrittene [SST28(1-13)]. As with CST, thrittene is not derived from PSST and is a product of a distinct gene, as supported by the presence of thrittene-like immunoreactivity in PSST deficient mice (Ensinck et al., 2003). Moreover, thrittene and SST are expressed by distinct cell populations and their release is triggered in response to different stimuli (Ensinck et al., 2002). With the exception of these initial studies nothing is known of the functional role of thrittene, nor if thrittene plays an analogous or discrete role to that of SST. A summary of SST and SST-like peptides is presented in Table 1.

\section{DISTRIBUTION OF ENDOGENOUS SSTR LIGANDS IN THE GI TRACT}

The GIT is the major source of SST and SST is a regulator of many digestive functions. SSTRs are an important therapeutic target in the treatment of digestive disease. In addition to its established role as a neurotransmitter, SST also acts in a hormonal and paracrine manner to regulate gut function (Low, 2004; Van Op den Bosch et al., 2009).

Somatostatin is expressed by D-cells of the stomach and plays a well-defined role in the control of acid secretion. SST negatively regulates gastrin release from antral $\mathrm{G}$ cells and histamine release from enterochromaffin-like cells, and acts directly on parietal cells leading to an SSTR2-dependent inhibition of acid release (Walsh, 1988; Lloyd et al., 1997; Low, 2004). SST-14 within the intestinal wall is mainly expressed by enteric neurons and potentially by extrinsic primary spinal afferents (Traub et al., 1999), although this is still debated (Keast and De Groat, 1992). SST-14 is also produced by macrophages during infection or inflammation as part of an immunoregulatory circuit with SSTR2 (Weinstock and Elliott, 2000). SST-28-distribution appears to be more restricted and is primarily expressed by enteroendocrine D-cells (Ravazzola et al., 1983; Baskin and Ensinck, 1984), consistent with the predominant release of SST-28 from the mucosa (Baldissera et al., 1985).

Myenteric SST-immunoreactivity is localized to a subclass of descending inhibitory interneuron, where it is co-expressed with choline acetyltransferase (Portbury et al., 1995; Song et al., 1997). Physiologically, SST is involved in the migrating myoelectric complex in the jejunum (Abdu et al., 2002) and propagating contractions of the colon (Grider, 2003). These actions are mediated through the SSTR2 receptor, which is expressed by NOS-positive inhibitory motor neurons or descending interneurons (Allen et al., 2002). SST is also an inhibitor of gastric emptying and of gall bladder contractility. SST is expressed by submucosal cholinergic secretomotor/ non-vasodilator neurons (Mongardi Fantaguzzi et al., 2009) and hyperpolarizes submucosal neurons (Shen and Surprenant, 1993) probably via SSTR1 and SSTR2 (Foong et al., 2010). In the human intestine SST is expressed by putative intrinsic primary afferent neurons of the submucosal plexus (Beyer et al., 2013).

There is limited information regarding the distribution of 'nonSST' peptides in the gut. Relatively high mRNA expression for CST has been detected through the human GIT (Dalm etal., 2004). However, it should be noted that with the exception of pancreatic delta islet cells (Papotti et al., 2003) and potentially 
Table 1 | Endogenous somatostatin (SST) peptide sequences (*sequence not confirmed).

\begin{tabular}{|c|c|c|}
\hline Precursor & Peptide & Sequence \\
\hline \multirow[t]{7}{*}{ Prosomatostatin (PSST) } & SST-28 & $\begin{array}{l}\text { Ser-Ala-Asn-Ser-Asn-Pro-Ala-Met-Ala-Pro-Arg-Glu-Arg-Lys-Ala-Gly-Cys-Lys-Asn-Phe-Phe-Trp- } \\
\text { Lys-Thr-Phe-Thr-Ser-Cys }\end{array}$ \\
\hline & SST-14 & Ala-Gly-Cys-Lys-Asn-Phe-Phe-Trp-Lys-Thr-Phe-Thr-Ser-Cys-OH \\
\hline & Neuronostatin (PPSST(31-43)) & Leu-Arg-GIn-Phe-Leu-GIn-Lys-Ser-Leu-Ala-Ala-Ala-Ala-NH2 \\
\hline & Antrin (SST-25-34) & Ala-Pro-Ser-Asp-Pro-Arg-Leu-Arg-GIn-Phe-OH \\
\hline & SST-28(1-14) & Ser-Ala-Asn-Ser-Asn-Pro-Ala-Met-Ala-Pro-Arg-Glu-Arg-Lys \\
\hline & SST-28(1-12) & Ser-Ala-Asn-Ser-Asn-Pro-Ala-Met-Ala-Pro-Arg-Glu \\
\hline & PPST 1-64 & $\begin{array}{l}\text { Ala-Pro-Ser-Asp-Pro-Arg-Leu-Arg-Gln-Phe-Leu-Gln-Lys-Ser-Leu-Ala-Ala-Ala-Ala-Gly-Lys-Gln-Glu- } \\
\text { Leu-Ala-Lys-Tyr-Phe-Leu-Ala-Glu-Leu-Leu-Ser-Glu-Pro-Asn-Gln-Thr-Glu-Asn-Asp-Ala-Leu-Glu- } \\
\text { Pro-Glu-Asp-Leu-Ser-GIn-Ala-Ala-Glu-Gln-Asp-Glu-Met-Arg-Leu-Glu-Leu-GIn-Arg }\end{array}$ \\
\hline \multirow[t]{3}{*}{ Preprocortistatin } & Cortistatin-14 (rat) & Pro-Cys-Lys-Asn-Phe-Phe-Trp-Lys-Thr-Phe-Ser-Ser-Cys-Lys \\
\hline & Cortistatin-17 (human) & Asp-Arg-Met-Pro-Cys-Arg-Asn-Phe-Phe-Trp-Lys-Thr-Phe-Ser-Ser-Cys-Lys \\
\hline & Cortistatin-29 & $\begin{array}{l}\text { H-Glu-Gly-Ala-Pro-Pro-Gln-Gln-Ser-Ala-Arg-Arg-Asp-Arg-Met-Pro-Cys-Arg-Asn-Phe-Phe-Trp- } \\
\text { Lys-Thr-Phe-Ser-Ser-Cys-Lys-OH }\end{array}$ \\
\hline Unknown & Thrittene (SST28(1-13)) & Ser-Ala-Asn-Ser-Asn-Pro-Ala-Met-Ala-Pro-Arg-Glu-Arg* \\
\hline
\end{tabular}

activated inflammatory cells (Gonzalez-Rey et al., 2006), the distribution of CST within the gut remains unknown. Thrittene-like immunoreactivity has been detected in enteroendocrine cells and enteric neurons and this distribution is distinct to that for SST14 and SST-28 (Ensinck et al., 2002). This is supported by the differential release of thrittene and SST in response to feeding (Ensinck et al., 2003). Antrin expression was originally believed to be restricted to gastric D-cells, where it is localized to SST28(1-12) containing secretory granules (Ravazzola et al., 1989; Benoit et al., 1990). However, this was contradicted by Rabbani and Patel (1990), who demonstrated comparable expression of antrin in the jejunal mucosa and pancreas by radioimmunoassay and HPLC.

\section{EVIDENCE FOR DIFFERENCES IN FUNCTION}

At present there is little evidence for significant differences in the effects of endogenous SSTs on GI function, although this may reflect the limited endpoints that have been assayed. Exposure of enteric neurons to SST results in activation of inwardly rectifying $\mathrm{K}^{+}$currents and to hyperpolarization, leading to inhibition of contractile and secretory activity (Van Op den Bosch et al., 2009). Direct electrophysiological recordings demonstrate no apparent difference in the acute effects of SST-14 and SST-28 on submucosal neurons, with exposure to either agonist leading to hyperpolarization and to rapid desensitization of responses (Shen and Surprenant, 1993). Similarly, there was no significant difference in the SST-14, SST-25, and SST-28 mediated inhibition of contractile activity. These agonists cross-desensitized responses to each other, but not to acetylcholine, suggesting actions at the same receptor (McIntosh et al., 1986). However, there is evidence for differences in the in vivo effects of SST-14 and SST-28 on both the stomach and intestine. For example, studies examining the direct effects of SSTR activation on gut function showed that SST-14 is significantly more potent at inhibiting gastric acid secretion than SST-28, despite the longer plasma half-life of SST28 (Hirst et al., 1982; Seal et al., 1982). Zhao et al. (2013) recently demonstrated that although SST-14 and SST-28 both stimulated endocytosis of SSTR2A in myenteric neurons, there were clear differences in receptor recycling. The apparent retention of SSTR2A following treatment of neurons with SST-28 was attributed to the greater resistance of this peptide to degradation by the endosomal endopeptidase endothelin-converting enzyme 1 (ECE-1). This study did not determine the consequences of this retention or prolonged endosomal SSTR2A signaling on gut function. Moreover, the possible biological activity of SST cleavage products resulting from ECE-1 activity was not examined. Intermediate products of both SST-14 (SST-1-10) and SST-28 (SST-1-24) retained the Phe-Trp-Lys-Thr motif at the extreme N-terminus and may represent novel SSTR agonists produced locally within endosomes. However, absence of a key N-terminal Cys residue suggests that these peptides lack the cyclopeptide structure characteristic of SSTs.

The existence of endogenous ligand bias has been examined at the SSTR2A. Comparison of the responses of SST-14, SST-28 and cortistatin has not showed any evidence of functional selectivity at this receptor. However, potential ligand bias has been suggested for the small molecule ligands that bind SSTR2A, albeit the quantification of this bias is lacking (Nunn et al., 2004; Liu et al., 2008; 
Cescato et al., 2010). More recently, we have shown that SST-14 and SST-28 show distinct profiles of receptor trafficking upon internalization (Zhao et al., 2013). After incubation with SST-14, SSTR2A recycled to the plasma membrane, which required the activity of the endosomal peptidase ECE-1, and an intact Golgi. In contrast, SSTR2A activated by SST-28, octreotide, lanreotide, or vapreotide was retained within the Golgi and did not recycle. Although ECE-1 rapidly degraded SST-14, SST-28 was resistant to degradation, and ECE-1 did not degrade the synthetic SST analogs. Thus, although no apparent bias was observed at the level of receptor signaling events, SST-14 and SST-28 differ in the trafficking of the receptor upon internalization. The differential regulation of SSTR2A may explain the different physiological effects of endogenous agonists and could account for the long-lasting therapeutic actions and side effects of clinically used agonists.

\section{THE OPIOID SYSTEM IN THE GUT}

Opioids and opiates are agonists of the mu, delta and kappa ORs (MOPr, DOPr, and KOPr). The nociceptin receptor (NOPr) was the last ORs to be cloned and is grouped with the ORs based on their high degree of sequence homology and its low level binding of opioids. The pharmacology and function of ORs has been reviewed extensively and will not be covered in detail in this review (Waldhoer et al., 2004). All receptors are expressed by enteric neurons and other cell types in the GIT and are major regulators of gut function (Wood and Galligan, 2004; Galligan and Akbarali, 2014)

The endogenous ligands for ORs are a large family of at least 20 different small peptides. The endogenous peptides have been detected throughout the central and peripheral nervous system as well as in other tissues, with similar distribution to the ORs. They are involved in numerous physiological processes including nociception, reward processing, and GIT motility and secretion. The distribution and physiological effects of endogenous opioids in the GIT have been the most extensively studied. However, identifying regions where endogenous opioids are expressed and released under normal physiological conditions has been challenging due to the high susceptibility of the peptides to degradation. Additionally, most studies have used antibody-based methods that may not reliably distinguish between different opioid peptides due to their high structural similarity, or HPLC-based methods which provide no detail of the specific cell types that express these peptides. Further complications arise due to interspecific differences and region-dependent variations in expression along the GIT. Nonetheless, most of the endogenous opioids are present in the GIT, and in some cases the distribution and release from discrete regions of the GIT has been thoroughly characterized.

There are three major classes of endogenous opioids (enkephalins, dynorphins, and endorphins), which are synthesized by proteolytic cleavage of precursor proteins; pro-enkephalin, prodynorphin, and pro-opiomelanocortin (POMC), respectively. The peptides range from 5 to 30 amino acids in length, and share a common N-terminal tetrapeptide sequence Tyr-Gly-Gly-Phe, with either a Leu or Met in the fifth position. These peptides have varying affinities for all three ORs, but none are highly selective for one receptor subtype (Mansour et al., 1995; Janecka et al., 2004). There are also two additional putative endogenous peptides; endomorphin-1, and endomorphin-2, which are structurally unrelated to the typical opioid peptides and are most selective and potent for MOPr (Zadina et al., 1997). The gene or genes encoding the precursor proteins of endomorphins are unknown (Terskiy etal., 2007), although a de novo synthesis mechanism has been proposed as an alternative source (Ronai etal., 2009). The presence of endomorphins in the GIT has not been reported and will not be discussed further in this review.

\section{DISTRIBUTION OF ENDOGENOUS OPIOID RECEPTOR LIGANDS IN THE GI TRACT}

Screening of the longitudinal muscle-myenteric plexus of the guinea pig ileum by HPLC identified expression of enkephalins (enk: Leu-enk, Met-enk, Met-enk-Arg-Gly-Leu, Met-enkArg-Phe, Metorphamide, and BAM-18) and dynorphins $[\alpha-$ neoendorphin, $\beta$-neoendorphin, dynorphin $\mathrm{A}(1-8)$, and dynorphin B]. No detectable beta endorphin was present in these preparations (Corbett et al., 1988).

\section{Enkephalins}

The enkephalins have been the most widely studied opioid peptides in the GIT. Pro-enkephalin contains four copies of Met-enk and one each of Leu-enk, Met-enk-Arg-Phe, and Met-enk-ArgGly-Leu, and several additional opioid peptides may be formed by partial processing of the precursor protein (see Table 2; Noda et al., 1982). Expression of at least four enkephalin peptides (Leuenk, Met-enk, Met-enk-Arg-Phe, and Met-enk-Arg-Gly-Leu) in the GIT has been confirmed (Hughes et al., 1977; Linnoila et al., 1978; Tang et al., 1982; Giraud et al., 1984). Immunohistochemical studies demonstrate expression throughout the human GIT, with highest levels detected in the muscularis externa (Polak et al., 1977; Ferri et al., 1986, 1988). A similar expression pattern has been observed in rodents (Keast et al., 1985). Enkephalin-derived peptides are mainly found in the cell bodies of myenteric neurons and in nerve fibers within the myenteric plexus and circular muscle (Elde et al., 1976; Jessen et al., 1980; Schultzberg et al., 1980; Furness et al., 1983). There is evidence that immunoreactivities for Leu-enk and Met-enk are expressed by distinct neuronal populations within the enteric nervous system (Linnoila et al., 1978; Larsson et al., 1979; Larsson and Stengaard-Pendersen, 1982). The morphology and distribution of Enk-containing myenteric neurons has been examined in detail. Approximately $23 \%$ of myenteric neurons express Enk-immunoreactivity (Furness et al., 1983). These are morphologically Dogiel Type I inhibitory or excitatory motor neurons and are also immunoreactive for ChAT and/ or substance P (Furness et al., 1983; Bornstein et al., 1984; Costa et al., 1985; Pfannkuche et al., 1998). Leu-enk-positive myenteric neurons of the human intestine have been described morphologically as 'stubby neurons' and are proposed to represent motor neurons or ascending interneurons (Brehmer et al., 2005). Examples of $\mathrm{OR}$ and enkephalin labeling in the intestine are presented in Figure 1.

There are a small number of neurons that express enkephalinimmunoreactivity in the submucosal plexus and fibers in the mucosa (Furness et al., 1985; Keast et al., 1985; Pfannkuche 
Table 2 | Endogenous opioid peptide sequences.

\begin{tabular}{|c|c|c|}
\hline Precursor & Peptide & Sequence \\
\hline \multirow[t]{12}{*}{ Pro-Enkephalin } & Leu-enkephalin & Tyr-Gly-Gly-Phe-Leu \\
\hline & Met-enkephalin & Tyr-Gly-Gly-Phe-Met \\
\hline & Met-enkephalin-Arg-Phe & Tyr-Gly-Gly-Phe-Met-Arg-Phe \\
\hline & Met-enkephalin-Arg-Gly-Leu & Tyr-Gly-Gly-Phe-Met-Arg-Gly-Leu \\
\hline & Metorphamide & Tyr-Gly-Gly-Phe-Met-Arg-Arg-Val \\
\hline & BAM 12 & Tyr-Gly-Gly-Phe-Met-Arg-Arg-Val-Gly-Arg-Pro-Glu \\
\hline & BAM 18 & Tyr-Gly-Gly-Phe-Met-Arg-Arg-Val-Gly-Arg-Pro-Glu-Trp-Trp-Met-Asp-Tyr-GIn \\
\hline & BAM 22 & Tyr-Gly-Gly-Phe-Met-Arg-Arg-Val-Gly-Arg-Pro-Glu-Trp-Trp-Met-Asp-Tyr-GIn-Lys-Arg-Tyr-Gly \\
\hline & Peptide E & Tyr-Gly-Gly-Phe-Met-Arg-Arg-Val-Gly-Arg-Pro-Glu-Trp-Trp-Met-Asp-Tyr-GIn-Lys-Arg-Tyr-Gly-Gly- \\
\hline & & Phe-Leu \\
\hline & Peptide F & Tyr-Gly-Gly-Phe-Met-Lys-Lys-Met-Asp-Glu-Leu-Tyr-Pro-Leu-Glu-Val-Glu-Glu-Glu-Ala-Asn-Gly-Gly- \\
\hline & & Glu-Val-Leu-Gly-Lys-Arg-Tyr-Gly-Gly-Phe-Met \\
\hline \multirow[t]{11}{*}{ Pro-Dynorphin } & Dynorphin A & Tyr-Gly-Gly-Phe-Leu-Arg-Arg-Ile-Arg-Pro-Lys-Leu-Lys-Trp-Asp-Asn-GIn \\
\hline & Dynorphin B & Tyr-Gly-Gly-Phe-Leu-Arg-Arg-GIn-Phe-Lys-Val-Val-Thr \\
\hline & Big Dynorphin (Dyn A/B 1-32) & Tyr-Gly-Gly-Phe-Leu-Arg-Arg-Ile-Arg-Pro-Lys-Leu-Lys-Trp-Asp-Asn-GIn-Lys-Arg-Tyr-Gly-Gly-Phe- \\
\hline & & Leu-Arg-Arg-GIn-Phe-Lys-Val-Val-Thr \\
\hline & Dynorphin A 1-13 & Tyr-Gly-Gly-Phe-Leu-Arg-Arg-Ile-Arg-Pro-Lys-Leu-Lys \\
\hline & Dynorphin A (1-8) & Tyr-Gly-Gly-Phe-Leu-Arg-Arg-Ile \\
\hline & Dynorphin A (1-6) & Tyr-Gly-Gly-Phe-Leu-Arg \\
\hline & Leumorphin & Tyr-Gly-Gly-Phe-Leu-Arg-Arg-Gln-Phe-Lys-Val-Val-Thr-Arg-Ser-GIn-Glu-Asp-Pro-Asn-Ala-Tyr-Tyr- \\
\hline & & Glu-Glu-Leu-Phe-Asp-Val \\
\hline & $\alpha$-neoendorphin & Tyr-Gly-Gly-Phe-Leu-Arg-Lys-Tyr-Pro-Lys \\
\hline & $\beta$-neoendorphin & Tyr-Gly-Gly-Phe-Leu-Arg-Lys-Tyr-Pro \\
\hline \multirow[t]{3}{*}{ Pro-Opiomelanocortin } & $\alpha$-endorphin & Tyr-Gly-Gly-Phe-Met-Thr-Ser-Glu-Lys-Ser-GIn-Thr-Pro-Val-Thr-Leu \\
\hline & $\beta$-endorphin & Tyr-Gly-Gly-Phe-Met-Thr-Ser-Glu-Lys-Ser-GIn-Thr-Pro-Val-Thr-Leu-Phe-Lys-Asn-Ile-Ile-Lys-Asn-Ala- \\
\hline & & Tyr-Lys-Lys-Gly-Glu \\
\hline \multirow[t]{2}{*}{ Unknown } & Endomorphin 1 & Tyr-Pro-Trp-Phe \\
\hline & Endomorphin 2 & Tyr-Pro-Phe-Phe \\
\hline
\end{tabular}

et al., 1998), and in enteroendocrine cells (Mimoda et al., 1998). However, it is possible that the enkephalin detected in these regions is due to detection of dynorphins or dynorphin derived Leu-enk which is highly expressed in these regions as discussed later in this review. Expression of other enkephalin derivatives including Met-enk-Arg-Phe (Bu'Lock et al., 1983) and Met-enk-Arg-Gly-Leu (Wang and Lindberg, 1986) by enteric neurons has also been demonstrated. Other sites where preproenkephalin and its derivatives are expressed include enteroendocrine cells (Bu'Lock etal., 1983; Nihei and Iwanaga, 1985; Kokrashvili etal., 2009), extrinsic afferents (Steele and Costa, 1990) and immune cells including CD4+ T cells (Boue et al., 2014).

\section{Dynorphins}

There is good evidence that opioid peptides derived from pro-dynorphin (dynorphins), are present in the GIT. Pre-prodynorphin mRNA is expressed in the myenteric and mucosal layers to varying levels throughout the GIT (Yuferov et al., 1998). Prodynorphin contains three opioid peptides, dynorphin A, dynorphin $B$, and $\alpha$-neoendorphin, which can all be further processed to shorter opioid peptides including Leu-Enk (see Table 2; Horikawa et al., 1983). Dynorphins have been detected in the GIT of various species, including the full length Dyn A (1-17), Dyn A (1-13), Dyn A (1-8), Dyn B, and $\alpha$-neoendorphin (Vincent et al., 1984; Wolter, 1986; Steele et al., 1989; Murphy and Turner, 1990; Spampinato et al., 1992). Dynorphins are present in all layers of the gut wall throughout the entire human GIT, although information regarding cellular sites of expression is lacking (Spampinato et al., 1988). Immunohistochemistry studies performed mainly in guinea pigs indicate that dynorphins are widely expressed by submucosal and myenteric neurons (Vincent et al., 1984; Wolter, 1986; Steele and Costa, 1990). Dynorphins are co-expressed with enkephalins in a subpopulation of Dogiel type I myenteric neurons (Costa et al., 1985; Furness et al., 1985; Steele and Costa, 1990). It is possible that this may reflect conversion of dynorphin to Leu-enk in these 


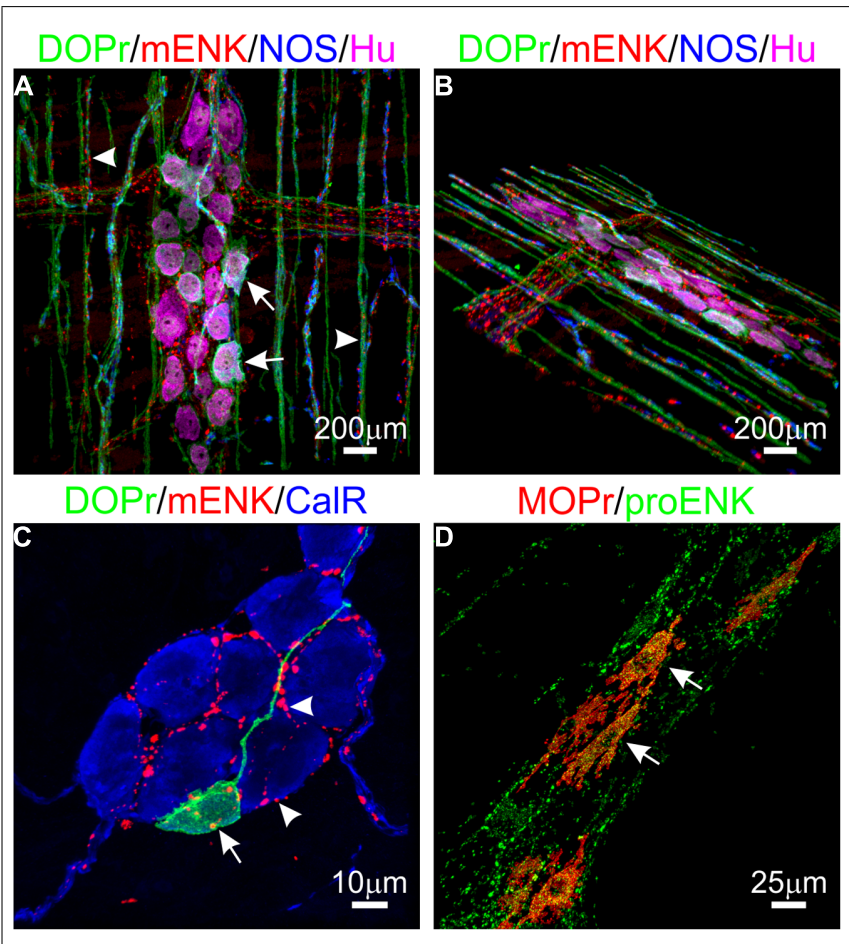

FIGURE 1 | Expression of opioid receptors (ORs) and enkephalin in the enteric nervous system. (A,B) Distribution of the delta opioid receptor (DOPr, green), met-enkephalin (mENK, red), nitric oxide synthase (NOS, blue), and the pan-neuronal marker HuC/D ( $\mathrm{Hu}$, magenta) in the myenteric plexus (arrows) and circular muscle nerve fibers (arrowheads) of the mouse distal colon. (C) Example of a DOPr-positive submucosal neuron (arrow) and association with mENK-immunoreactive nerve varicosities (arrowheads) in the mouse distal colon. (D) Overlap between immunoreactivities for the Mu opioid receptor (MOPr, red) and proenkephalin (proENK, green) in myenteric neurons of the guinea pig ileum. Images have been modified using Imaris 7.4 .2 software (Bitplane). Scale bars are as indicated.

neurons rather than co-expression of pro-enkephalin. There are also reports of dynorphin expression by enterochromaffin cells (Cetin, 1988).

\section{Endorphins}

The endorphins are formed from the precursor peptide POMC, which also contains several other non-opioid peptide hormones (Eipper and Mains, 1978). POMC contains only one opioid peptide, $\beta$-endorphin, which can be cleaved to form $\alpha$-endorphin. Although $\beta$-endorphin has been detected in the GIT (Orwoll and Kendall, 1980; DeBold et al., 1988), the localization of endorphin expression still remains uncertain. There is some evidence of $\beta$ endorphin expression, and of other POMC peptides, by myenteric neurons, nerve fibers within the circular muscle and enteroendocrine cells (Schultzberg et al., 1980; Leander et al., 1984; Wolter, 1985b; Kokrashvili et al., 2009; Miller and Hirning, 2010). Another major source of $\beta$-endorphin in the gut are immune cells, particularly those associated with inflammatory bowel disease or irritable bowel syndrome (Verma-Gandhu et al., 2006; Hughes et al., 2013). It should be noted that the distribution of $\beta$-endorphin in the GIT is controversial, as the specificity of the antisera used in many of these studies has been questioned (Sundler et al., 1981).
Hence whilst there is certainly $\beta$-endorphin present in the GIT, the question of its origin remains unresolved.

Other OR agonists are also produced endogenously in the GIT. These include morphine and codeine-like compounds (Schulz et al., 1977; Laux-Biehlmann et al., 2013) and the pre-dermorphin derivatives dermorphin and dermenkephalin (Mor et al., 1989, 1990).

Even though the distribution of the different classes of endogenous opioids in the GIT has been fairly well established, there is very little known about individual levels of the different peptides within each class. The expression of proteases that synthesize and degrade endogenous opioids may have varying levels of expression in different cell types, which would result in different production and degradation rates. As such, the mixture of opioid peptides derived from the same precursor will be variable in different cell populations. Differential proteolytic processing of pro-enkephalin and pro-dynorphin peptides occurs in various regions of the brain and other tissues, leading to variations in the relative proportions of peptides derived from the same precursors (Cone et al., 1983; Zamir et al., 1984; Yakovleva et al., 2006). Differential processing of precursors may also occur in the different cell populations within the GIT. In rat duodenum, specific antisera against Dyn A (1-17) and Dyn A (1-8) stain two distinct populations of neurons, one which contains both peptides and one with only Dyn A (1-8), indicating that Dyn A (1-8) may be synthesized via distinct proteases or at varying rates in distinct neuronal populations (Wolter, 1985a).

\section{FUNCTION OF ENDOGENOUS OPIOID RECEPTOR LIGANDS IN THE GI TRACT}

Endogenous opioids play an important regulatory role in normal gut physiology, primarily through activation of ORs on enteric neurons (Wood and Galligan, 2004). When applied exogenously, the physiological effects of endogenous opioids are the same as the effects of other opioids, they hyperpolarize enteric neurons leading to inhibition of GIT motility and secretion and ultimately cause constipation (Miller and Hirning, 2010). On the other hand, the effects of endogenous peptides when released intrinsically under normal physiological conditions are unclear. Release of enkephalin- and dynorphin-derived peptides has been detected in intestinal tissue preparations during peristalsis or after electrical stimulation. These include Leu-enk, Met-enk, Met-enk-Arg-Phe, Met-enk-Arg-Gly-Leu, metorphamide (Schulz et al., 1977; Corbett et al., 1991), $\alpha$-neoendorphin (Majeed et al., 1987) and Dyn A (Kromer etal., 1981; Donnerer et al., 1984). In addition, studies using opioid antagonists, mainly naloxone, have shown that inhibition of opioid activity increases non-propagating intestinal motility (Sanger and Tuladhar, 2004). Altogether, this shows that endogenous opioids play a subtle but important role in control of GIT motility by suppressing activity. There is also evidence that the endogenous peptides either contribute to, or protect against, the development of pathophysiological conditions. Levels of endogenous opioids in the GIT have been shown to increase under pathological conditions, including inflammatory bowel disease, and not only inhibit gastrointestinal motility, but also provide visceral antinociception. $\beta$-endorphin levels have been shown to increase in a 
model of chronic inflammatory bowel disease in mice, suppressing inflammation-associated hyperexcitability of colonic primary spinal afferents (Hughes et al., 2013; Valdez-Morales et al., 2013). In addition, $\mathrm{T}$ Lymphocytes can release $\beta$-endorphin and induce expression of $\beta$-endorphin in the myenteric plexus in mice with immunodeficiency-related visceral hyperalgesia (Verma-Gandhu et al., 2006, 2007). Surgical intervention has also been shown to increase dynorphin expression in the dorsal root ganglia of mice (Romero et al., 2012), and stimulate release of opioid peptides from enteric neurons after abdominal surgery in guinea pigs (Patierno etal., 2005). This may contribute in part to post-operative ileus, although sympathetic pathways are likely to play a more significant role. A greater understanding of the involvement of endogenous opioids in GIT pathophysiology is important as the opioid system is not only a potential target for treatment, but the enhanced production and release of endogenous opioids may also alter the effectiveness of opioid-based therapeutics.

Although the global physiological effects of endogenous opioids in the GIT have been widely studied, the role of individual peptides in the control of normal GIT functions or pathophysiological conditions in discrete regions is still not clear. There are specific distributions of endogenous opioids throughout the GIT. However, since all endogenous opioids can activate all ORs, the specific ORs through which endogenous opioids exert their actions or the specific signaling mechanisms behind these functions is unknown. The physiological significance of such diversity and structural organization of opioid peptides suggests that individual endogenous peptides may serve distinct physiological roles. The diversity in physiological effects can in part be achieved by activation of the different ORs. However, as there are far more endogenous opioids than there are receptors and little receptor selectivity, it is probable that the diversity in endogenous opioids exists to fine tune OR-mediated effects through biased agonism.

\section{BIASED AGONISM AT THE OPIOID RECEPTORS}

Opioid receptors are prototypical GPCRs where biased agonism displayed by synthetic and exogenous ligands has been widely explored. Indeed, this reflects the extensive knowledge of opioid physiology and the desire to generate opioid-based analgesics devoid of limiting side effects such as respiratory depression or constipation.

In addition to the ideal separation of therapeutic and clinically limiting side effects, two key observations in the actions of morphine at MOPr have sparked the search for biased agonists at this receptor. First, morphine is relatively poor at inducing $\mathrm{MOPr}$ internalization, in spite of its efficacy in mediating G-protein activation, and second, morphine-induced respiratory depression and constipation were attenuated in a $\beta$-arrestin knock-out mouse, while analgesia was enhanced. Altogether these reports have sparked the search for potentially different signaling mechanisms that mediate the diverse physiological actions of ORs. Similarly, reports of biased agonism by exogenous ligands have also been described for the other OR subtypes, DOPr (Charfi et al., 2014), and KOPr (Melief et al., 2010). However, the potential for endogenous bias at the OR family has not received much attention. This is despite the fact that, as highlighted above, there is significant biological redundancy in the opioid system. In a systematic approach to evaluate biased agonism at the mu-OR, McPherson et al. (2010; Rivero et al., 2012) examined the signaling bias of a wide range of ligands including endogenous opioid peptides and synthetic opioids. In these and subsequent studies, endomorphin-2 as well as endomorphin-1 showed statistically significant bias toward $\beta$-arrestin 2 recruitment and away from $\mathrm{G}$ protein activation. However, as neither the gene nor the precursor protein of endomorphin 1 and two has yet been identified, their classification as endogenous opioids is still a matter of debate.

Opioid receptors have also been reported to form homoand hetero-dimers. Importantly, it has been suggested that these dimers may indeed form a new signaling entity where the intracellular signaling resulting from the activation of heterodimers may be different from that elicited by the individual protomers or homodimers (Waldhoer et al., 2005; Rozenfeld and Devi, 2007; Gomes et al., 2013). Moreover, some of these dimers have been demonstrated to exist in vivo (Massotte, 2014). Although such mechanisms of engendering distinct intracellular signals would not fall into the definition of biased agonism, it is another paradigm to take into account in the context of the differential actions of endogenous opioid peptides.

\section{IDENTIFICATION AND QUANTIFICATION OF BIASED AGONISM: CHALLENGES AND LIMITATIONS}

Although biased agonism offers the potential of safer and more effective therapeutics, there are still significant limitations for its detection, quantification and, importantly, its translation into differential physiological responses.

\section{QUANTIFICATION OF BIASED AGONISM}

Analytical tools for the detection and quantification of biased agonism are necessary in order to effectively inform future drug development efforts aimed in this direction. The majority of studies to date on biased agonism have used largely qualitative observations, such as reversals in agonist potency orders or maximal agonist effects between different pathways. However, such approaches are not optimal. The potency of a ligand is determined by both its affinity for the receptor state coupled to that particular pathway as well as its intrinsic efficacy for generating a response in that pathway. In contrast, the maximal effect of a ligand at saturating concentrations is only determined by intrinsic efficacy. In addition, contributors to system bias, signal amplification, and receptor expression need to be taken into account as they have markedly different effects on potencies and efficacies of differently efficacious ligands. Therefore, the observed response of an agonist at a given pathway is not only the result of unique ligand-induced receptor conformations, rather it is affected by "system bias," which reflects the differing coupling efficiencies of the receptor to a given signaling pathway, and by "observation bias," which results from differing assay sensitivity and conditions (Kenakin et al., 2012; Kenakin and Christopoulos, 2013a). It is the bias imposed by the ligand on the receptor that is the only source of bias that allows the signaling bias profiles of ligands in different cell types to be compared. It is 
therefore important to quantify signaling bias in such a way that it excludes system and observation bias, in order to reveal the unique signaling profile that is induced by the different ligands.

Several analytical approaches have been described to quantify biased agonism (reviewed by Kenakin and Christopoulos, 2013b). The relative transduction ratio (Kenakin et al., 2012) is one of the most robust and widely applicable methods for bias quantification. This method applies the operational model of agonism first derived by Black and Leff (1983) to concentration-response curves and estimates a "transduction coefficient" which is comprised of the functional equilibrium dissociation constant (a measure of the affinity for the receptor coupled to a particular effector protein or signaling pathway) and the intrinsic efficacy of the agonist in activating a particular signaling response and receptor density. This coefficient is thus an overall measure of the relative 'power' of an agonist to induce a response. In order to eliminate the effects of system and observation bias, normalization to a reference agonist is required. Finally, these normalized transduction coefficients can be compared across two signaling pathways for a given agonist to obtain the "relative transduction ratio" as measures of agonist bias. It is, however, important to highlight that key factors need to be considered [reference ligand, cellular content and pluridimensionality of efficacy, (Thompson et al., 2014)] which influence the identification and quantification of biased agonism and that need to be taken into account when interpreting information obtained from studying biased signaling in vitro.

\section{EXAMINATION OF ENDOGENOUS BIAS IN A PHYSIOLOGICAL SETTING}

Potentially insurmountable difficulties may prevent the examination of endogenous ligand bias in tissues and in vivo. First and foremost, multiple agonists for the same receptor exist, and these may be coexpressed (e.g., enkephalins), precluding differential release protocols. Selective stimulation of release may be possible in cases where agonists are expressed by distinct cells or neuronal subtypes (e.g., enteric neurons vs. enteroendocrine cells). Peptides may differ with respect to their susceptibility to degradation, complicating interpretation of studies of duration or magnitude of effects. Furthermore, these peptides may vary in their relative affinities to receptors of interest. The endpoints that are measured are often indirect and result from activation of complex reflex pathways involving a number of transmitters. For example, suppression of electrically evoked intestinal contractions, such as occurs in response to OR agonists (Wood and Galligan, 2004) may not reveal subtle agonist-dependent differences. Most of the current descriptions of biased agonism rely on direct measurements from cells (e.g., pERK1/2, cAMP accumulation, $\beta$-arrestin-recruitment), which are difficult to assay in enteric neurons. Moreover, the effects of exogenous agonist application may not reflect what occurs physiologically, as location of receptors and ligands may mean that such interactions never occur.

Other factors to consider when translating data derived from heterologous cell lines to enteric neurons, tissues, or in vivo studies include not only species, but also regional differences, and the relative expression of key regulatory proteins in the cellular environment examined. These factors are most apparent in the case of the ORs. The distribution of ORs in the gut differs between species. For example, there is limited evidence for functional DOPr expression in the guinea pig ileum (Johnson et al., 1987), whereas there is prominent DOPr expression in the mouse ileum (Poole et al., 2011). There may also be differences in the regional distribution of ORs with respect to both the relative numbers of positive neurons and in the neuronal types that express these receptors, as we have previously demonstrated for the DOPr (Poole et al., 2011). Interestingly, this does not appear to be the case for MOPr expression in the guinea pig ileum and colon where similar neuronal populations express the receptor (Poole et al., unpublished). It is worth noting that these differences in distribution are unlikely to have an effect in the detection of bias, as measurements are likely to be performed in the same tissue preparation. However, species and regional differences in OR expression will affect the potential for heterodimerization of ORs, which may influence the pharmacological profiles of any responses to agonists (Rozenfeld and Devi, 2007). Perhaps of greater importance is the relative expression of key modulatory proteins including $\beta$-arrestins and GRKs, which influence OR signaling in enteric neurons. This is highlighted by a number of recent studies using knockout mice. $\beta$-arrestin 2 deficient mice exhibit reduced constipatory effects of morphine and loperamide based on assays of fecal output and colonic transit (Raehal et al., 2005). Similarly, GRK6 ${ }^{-/-}$mice also display significantly diminished opiate-induced inhibition of colonic transit relative to wildtype mice (Raehal et al., 2009). Deletion of either $\beta$-arrestin 2 or GRK6 did not affect morphine-induced inhibition of small intestinal transit, suggesting region-dependent regulation of neuronal MOR. $\beta$-arrestins are also integral to the development of opiate tolerance in the intestine, with deletion of $\beta$-arrestin 2 promoting acute morphine tolerance in the colon (Maguma et al., 2012; Akbarali et al., 2014). These studies highlight that OR regulation and physiological function can differ markedly between regions of the GIT and the difficulty in translating data obtained from model cell systems to the physiological setting.

In summary, we have provided an overview of the expression and distribution of endogenous ligands for two major therapeutically relevant classes of GPCRs in the GIT. We have provided evidence for functional selectivity of these ligands and have discussed potential issues related to translation of cell line-derived data to the organ and whole animal levels. Therapeutically, the targeting of selective release of endogenous peptides is probably not a realistic goal. However, understanding the fundamental basis for ligand bias and determining whether differences in the expression and release of endogenous ligands underlie the development and maintenance of disease may be more promising avenues to address and to provide mechanistic insight for the development of safer therapies.

\section{ACKNOWLEDGMENTS}

NHMRC Australia APP1049730 (Daniel P. Poole, Meritxell Canals), Monash Fellowship (Meritxell Canals), and the Defence Science and Technology Organisation Australia (Georgina L. Thompson). The authors thank Dr. Dane Jensen for assistance with figure preparation. 


\section{REFERENCES}

Abdu, F., Hicks, G. A., Hennig, G., Allen, J. P., and Grundy, D. (2002). Somatostatin sst(2) receptors inhibit peristalsis in the rat and mouse jejunum. Am. J. Physiol. Gastrointest. Liver Physiol. 282, G624-G633. doi: 10.1152/ajpgi.00354.2001

Akbarali, H. I., Inkisar, A., and Dewey, W. L. (2014). Site and mechanism of morphine tolerance in the gastrointestinal tract. Neurogastroenterol. Motil. 26, 1361-1367. doi: 10.1111/nmo.12443

Allen, J. P., Canty, A. J., Schulz, S., Humphrey, P. P., Emson, P. C., and Young, H. M. (2002). Identification of cells expressing somatostatin receptor 2 in the gastrointestinal tract of Sstr2 knockout/lacZ knockin mice. J. Comp. Neurol. 454, 329-340. doi: 10.1002/cne.10466

Baldissera, F. G., Nielsen, O. V., and Holst, J. J. (1985). The intestinal mucosa preferentially releases somatostatin-28 in pigs. Regul. Pept. 11, 251-262. doi: 10.1016/0167-0115(85)90057-6

Baskin, D. G., and Ensinck, J. W. (1984). Somatostatin in epithelial cells of intestinal mucosa is present primarily as somatostatin 28. Peptides 5, 615-621. doi: 10.1016/0196-9781(84)90092-5

Benoit, R., Esch, F., Bennett, H. P., Ling, N., Ravazzola, M., Orci, L., et al. (1990). Processing of prosomatostatin. Metabolism 39, 22-25. doi: 10.1016/00260495(90)90202-N

Benoit, R., Ling, N., and Esch, F. (1987). A new prosomatostatin-derived peptide reveals a pattern for prohormone cleavage at monobasic sites. Science 238, 1126-1129. doi: 10.1126/science. 2891188

Bersani, M., Thim, L., Baldissera, F. G., and Holst, J. J. (1989). Prosomatostatin 1-64 is a major product of somatostatin gene expression in pancreas and gut. J. Biol. Chem. 264, 10633-10636.

Beyer, J., Jabari, S., Rau, T. T., Neuhuber, W., and Brehmer, A. (2013). Substance P- and choline acetyltransferase immunoreactivities in somatostatincontaining, human submucosal neurons. Histochem. Cell Biol. 140, 157-167. doi: 10.1007/s00418-013-1078-9

Black, J. W., and Leff, P. (1983). Operational models of pharmacological agonism. Proc. R. Soc. Lond. B Biol. Sci. 220, 141-162. doi: 10.1098/rspb.1983.0093

Bohlen, P., Brazeau, P., Benoit, R., Ling, N., Esch, F., and Guillemin, R. (1980). Isolation and amino acid composition of two somatostatin-like peptides from ovine hypothalamus: somatostatin-28 and somatostatin-25. Biochem. Biophys. Res. Commun. 96, 725-734. doi: 10.1016/0006-291X(80)91415-1

Bokoch, M. P., Zou, Y., Rasmussen, S. G., Liu, C. W., Nygaard, R., Rosenbaum, D. M., et al. (2010). Ligand-specific regulation of the extracellular surface of a G-protein-coupled receptor. Nature 463, 108-112. doi: 10.1038/nature08650

Bornstein, J. C., Costa, M., Furness, J. B., and Lees, G. M. (1984). Electrophysiology and enkephalin immunoreactivity of identified myenteric plexus neurones of guinea-pig small intestine. J. Physiol. 351, 313-325.

Boue, J., Basso, L., Cenac, N., Blanpied, C., Rolli-Derkinderen, M., Neunlist, M., et al. (2014). Endogenous regulation of visceral pain via production of opioids by colitogenic CD4(+) T cells in mice. Gastroenterology 146, 166-175. doi: 10.1053/j.gastro.2013.09.020

Brazeau, P., Ling, N., Esch, F., Bohlen, P., Benoit, R., and Guillemin, R. (1981). High biological activity of the synthetic replicates of somatostatin-28 and somatostatin-25. Regul. Pept. 1, 255-264. doi: 10.1016/0167-0115(81)90048-3

Brazeau, P., Vale, W., Burgus, R., Ling, N., Butcher, M., Rivier, J., et al. (1973). Hypothalamic polypeptide that inhibits the secretion of immunoreactive pituitary growth hormone. Science 179, 77-79. doi: 10.1126/science.179.4068.77

Brehmer, A., Lindig, T. M., Schrodl, F., Neuhuber, W., Ditterich, D., Rexer, M., et al. (2005). Morphology of enkephalin-immunoreactive myenteric neurons in the human gut. Histochem. Cell Biol. 123, 131-138. doi: 10.1007/s00418-005-0757-6

Bu'Lock, A. J., Vaillant, C., and Dockray, G. J. (1983). Immunohistochemical studies on the gastrointestinal tract using antisera to Met-enkephalin and Met-enkephalin Arg6Phe7. J. Histochem. Cytochem. 31, 1356-1362. doi: 10.1177/31.12.6355286

Cescato, R., Loesch, K. A., Waser, B., Macke, H. R., Rivier, J. E., Reubi, J. C., et al. (2010). Agonist-biased signaling at the sst $2 \mathrm{~A}$ receptor: the multi-somatostatin analogs KE108 and SOM230 activate and antagonize distinct signaling pathways. Mol. Endocrinol. 24, 240-249. doi: 10.1210/me.2009-0321

Cetin, Y. (1988). Enterochromaffin (EC-) cells of the mammalian gastro-enteropancreatic (GEP) endocrine system: cellular source of pro-dynorphin-derived peptides. Cell Tissue Res. 253, 173-179. doi: 10.1007/BF00221752

Charfi, I., Audet, N., Bagheri Tudashki, H., and Pineyro, G. (2014). Identifying ligand-specific signalling within biased responses: focus on delta opioid receptor ligands. Br. J. Pharmacol. doi: 10.1111/bph.12705 [Epub ahead of print].
Cone, R. I., Weber, E., Barchas, J. D., and Goldstein, A. (1983). Regional distribution of dynorphin and neo-endorphin peptides in rat brain, spinal cord, and pituitary. J. Neurosci. 3, 2146-2152.

Corbett, A. D., Gillan, M. G., and Kosterlitz, H. W. (1991). Electrically-induced release of opioid peptides from the guinea-pig myenteric plexus preparation. J. Recept. Res. 11, 665-673. doi: 10.3109/10799899109066434

Corbett, A. D., Mcknight, A. T., and Kosterlitz, H. W. (1988). Tissue content of opioid peptides in the myenteric plexus-longitudinal muscle of guinea-pig small intestine. J. Neurochem. 51, 32-37. doi: 10.1111/j.1471-4159.1988.tb04831.x

Costa, M., Furness, J. B., and Cuello, A. C. (1985). Separate populations of opioid containing neurons in the guinea-pig intestine. Neuropeptides 5, 445-448. doi: 10.1016/0143-4179(85)90050-2

Dalm, V. A., Van Hagen, P. M., De Krijger, R. R., Kros, J. M., Van Koetsveld, P. M., Van Der Lely, A. J., et al. (2004). Distribution pattern of somatostatin and cortistatin mRNA in human central and peripheral tissues. Clin. Endocrinol. 60, 625-629. doi: 10.1111/j.1365-2265.2004.02024.x

DeBold, C. R., Nicholson, W. E., and Orth, D. N. (1988). Immunoreactive proopiomelanocortin (POMC) peptides and POMC-like messenger ribonucleic acid are present in many rat nonpituitary tissues. Endocrinology 122, 2648-2657. doi: 10.1210/endo-122-6-2648

de Lecea, L., Criado, J. R., Prospero-Garcia, O., Gautvik, K. M., Schweitzer, P., Danielson, P. E., et al. (1996). A cortical neuropeptide with neuronal depressant and sleep-modulating properties. Nature 381, 242-245. doi: 10.1038/ $381242 \mathrm{a} 0$

Deupi, X., and Kobilka, B. K. (2010). Energy landscapes as a tool to integrate GPCR structure, dynamics, and function. Physiology (Bethesda) 25, 293-303. doi: 10.1152/physiol.00002.2010

Donnerer, J., Holzer, P., and Lembeck, F. (1984). Release of dynorphin, somatostatin and substance $\mathrm{P}$ from the vascularly perfused small intestine of the guinea-pig during peristalsis. Br. J. Pharmacol. 83, 919-925. doi: 10.1111/j.14765381.1984.tb16532.x

Eipper, B. A., and Mains, R. E. (1978). Analysis of the common precursor to corticotropin and endorphin. J. Biol. Chem. 253, 5732-5744.

Elde, R., Hokfelt, T., Johansson, O., and Terenius, L. (1976). Immunohistochemical studies using antibodies to leucine-enkephalin: initial observations on the nervous system of the rat. Neuroscience 1, 349-351. doi: 10.1016/03064522(76)90063-4

Ensinck, J. W., Baskin, D. G., Vahl, T. P., Vogel, R. E., Laschansky, E. C., Francis, B. H., et al. (2002). Thrittene, homologous with somatostatin-28((1-13)), is a novel peptide in mammalian gut and circulation. Endocrinology 143, 2599-2609. doi: 10.1210/endo.143.7.8904

Ensinck, J. W., Laschansky, E. C., Vogel, R. E., and D'alessio, D. A. (2003). Effect of ingested nutrients on the release of thrittene into the human circulation. J. Clin. Endocrinol. Metab. 88, 4798-4804. doi: 10.1210/jc.2003-030063

Esch, F., Bohlen, P., Ling, N., Benoit, R., Brazeau, P., and Guillemin, R. (1980). Primary structure of ovine hypothalamic somatostatin-28 and somatostatin-25. Proc. Natl. Acad. Sci. U.S.A. 77, 6827-6831. doi: 10.1073/pnas.77.11.6827

Ferri, G. L., Morreale, R. A., and Dockray, G. J. (1986). Met5-enkephalin-Arg6-Gly7Leu8 immunoreactivity in the human gut. Peptides 7, 735-739. doi: 10.1016/01969781(86)90087-2

Ferri, G. L., Watkinson, A., and Dockray, G. J. (1988). Proenkephalin A-derived peptides in the human gut. Gastroenterology 95, 1011-1017.

Foong, J. P., Parry, L. J., Gwynne, R. M., and Bornstein, J. C. (2010). 5-HT(1A), SST(1), and SST(2) receptors mediate inhibitory postsynaptic potentials in the submucous plexus of the guinea pig ileum. Am. J. Physiol. Gastrointest. Liver Physiol. 298, G384-G394. doi: 10.1152/ajpgi.00438.2009

Francis, B. H., Baskin, D. G., Saunders, D. R., and Ensinck, J. W. (1990). Distribution of somatostatin-14 and somatostatin-28 gastrointestinal-pancreatic cells of rats and humans. Gastroenterology 99, 1283-1291.

Furness, J. B., Costa, M., Gibbins, I. L., Llewellyn-Smith, I. J., and Oliver, J. R. (1985). Neurochemically similar myenteric and submucous neurons directly traced to the mucosa of the small intestine. Cell Tissue Res. 241, 155-163. doi: 10.1007/BF00214637

Furness, J. B., Costa, M., and Miller, R. J. (1983). Distribution and projections of nerves with enkephalin-like immunoreactivity in the guinea-pig small intestine. Neuroscience 8, 653-664. doi: 10.1016/0306-4522(83)90001-5

Galligan, J. J., and Akbarali, H. I. (2014). Molecular physiology of enteric opioid receptors. Am. J. Gastroenterol. 2, 17-21. doi: 10.1038/ajgsup.2014.5 
Giraud, A. S., Williams, R. G., and Dockray, G. J. (1984). Evidence for different patterns of post-translational processing of pro-enkephalin in the bovine adrenal, colon and striatum indicated by radioimmunoassay using region-specific antisera to Met-Enk-Arg6-Phe7 and Met-Enk-Arg6-Gly7-Leu8. Neurosci. Lett. 46, 223 228. doi: 10.1016/0304-3940(84)90446-4

Gomes, I., Fujita, W., Gupta, A., Saldanha, S. A., Negri, A., Pinello, C. E., et al. (2013). Identification of a mu-delta opioid receptor heteromer-biased agonis with antinociceptive activity. Proc. Natl. Acad. Sci. U.S.A. 110, 12072-12077. doi: 10.1073/pnas.1222044110

Gonzalez-Rey, E., Varela, N., Sheibanie, A. F., Chorny, A., Ganea, D., and Delgado, M. (2006). Cortistatin, an antiinflammatory peptide with therapeutic action in inflammatory bowel disease. Proc. Natl. Acad. Sci. U.S.A. 103, 4228-4233. doi: 10.1073/pnas.0508997103

Grider, J. R. (2003). Neurotransmitters mediating the intestinal peristaltic reflex in the mouse. J. Pharmacol. Exp. Ther. 307, 460-467. doi: 10.1124/jpet.103.053512

Hirst, B. H., Conlon, J. M., Coy, D. H., Holland, J., and Shaw, B. (1982). Comparison of the gastric exocrine inhibitory activities and plasma kinetics of somatostatin28 and somatostatin-14 in cats. Regul. Pept. 4, 227-237. doi: 10.1016/01670115(82)90115-X

Hofmann, K. P., Scheerer, P., Hildebrand, P. W., Choe, H. W., Park, J. H., Heck, M., et al. (2009). A G protein-coupled receptor at work: the rhodopsin model. Trends Biochem. Sci. 34, 540-552. doi: 10.1016/j.tibs.2009.07.005

Horikawa, S., Takai, T., Toyosato, M., Takahashi, H., Noda, M., Kakidani, H., et al. (1983). Isolation and structural organization of the human preproenkephalin B gene. Nature 306, 611-614. doi: 10.1038/30661la0

Hughes, J., Kosterlitz, H. W., and Smith, T. W. (1977). The distribution of methionine-enkephalin and leucine-enkephalin in the brain and peripheral tissues. Br. J. Pharmacol. 61, 639-647. doi: 10.1111/j.1476-5381.1977. tb07557.x

Hughes, P. A., Harrington, A. M., Castro, J., Liebregts, T., Adam, B., Grasby, D. J. et al. (2013). Sensory neuro-immune interactions differ between irritable bowe syndrome subtypes. Gut 62, 1456-1465. doi: 10.1136/gutjnl-2011-301856

Janecka, A., Fichna, J., and Janecki, T. (2004). Opioid receptors and their ligands. Curr. Top. Med. Chem. 4, 1-17. doi: 10.2174/1568026043451618

Jessen, K. R., Saffrey, M. J., Van Noorden, S., Bloom, S. R., Polak, J. M., and Burnstock, G. (1980). Immunohistochemical studies of the enteric nervous system in tissue culture and in situ: localization of vascoactive intestinal polypeptide (VIP), substance-P and enkephalin immunoreactive nerves in the guinea-pig gut. Neuroscience 5, 1717-1735. doi: 10.1016/0306-4522(80)90091-3

Johnson, S. M., Costa, M., Humphreys, C. M., and Shearman, R. (1987) Inhibitory effects of opioids in a circular muscle-myenteric plexus preparation of guinea-pig ileum. Naunyn Schmiedebergs Arch. Pharmacol. 336, 419-424. doi: 10.1007/BF00164876

Keast, J. R., and De Groat, W. C. (1992). Segmental distribution and peptide content of primary afferent neurons innervating the urogenital organs and colon of male rats. J. Comp. Neurol. 319, 615-623. doi: 10.1002/cne.903190411

Keast, J. R., Furness, J. B., and Costa, M. (1985). Distribution of certain peptidecontaining nerve fibres and endocrine cells in the gastrointestinal mucosa in five mammalian species. J. Comp. Neurol. 236, 403-422. doi: 10.1002/cne. 902360308

Kenakin, T., and Christopoulos, A. (2013a). Measurements of ligand bias and functional affinity. Nat. Rev. Drug Discov. 12, 483. doi: 10.1038/nrd3954-c2

Kenakin, T., and Christopoulos, A. (2013b). Signalling bias in new drug discovery: detection, quantification and therapeutic impact. Nat. Rev. Drug Discov. 12, 205-216. doi: 10.1038/nrd3954

Kenakin, T., Watson, C., Muniz-Medina, V., Christopoulos, A., and Novick, S. (2012). A simple method for quantifying functional selectivity and agonist bias. ACS Chem. Neurosci. 3, 193-203. doi: 10.1021/cn200111m

Kokrashvili, Z., Rodriguez, D., Yevshayeva, V., Zhou, H., Margolskee, R. F., and Mosinger, B. (2009). Release of endogenous opioids from duodenal enteroendocrine cells requires Trpm5. Gastroenterology 137, 598-606; 606.e1-e2. doi: 10.1053/j.gastro.2009.02.070

Kromer, W., Hollt, V., Schmidt, H., and Herz, A. (1981). Release of immunoreactivedynorphin from the isolated guinea-pig small intestine is reduced during peristaltic activity. Neurosci. Lett. 25, 53-56. doi: 10.1016/0304-3940(81)90100-2

Larsson, L. I., Childers, S., and Snyder, S. H. (1979). Met- and Leuenkephalin immunoreactivity in separate neurones. Nature 282, 407-410. doi: $10.1038 / 282407 \mathrm{a} 0$
Larsson, L. I., and Stengaard-Pendersen, K. (1982). Immunocytochemical and ultrastructural differentiation between Met-enkephalin-, Leu-enkephalin-, and Met/Leu-enkephalin-immunoreactive neurons of feline gut. J. Neurosci. 2, 861-878.

Laux-Biehlmann, A., Mouheiche, J., Veriepe, J., and Goumon, Y. (2013). Endogenous morphine and its metabolites in mammals: history, synthesis, localization and perspectives. Neuroscience 233, 95-117. doi: 10.1016/j.neuroscience.2012. 12.013

Leander, S., Ekman, R., Uddman, R., Sundler, F., and Hakanson, R. (1984). Neuronal cholecystokinin, gastrin-releasing peptide, neurotensin, and beta-endorphin in the intestine of the guinea pig. Distribution and possible motor functions. Cell Tissue Res. 235, 521-531. doi: 10.1007/BF00226949

Linnoila, R. I., Diaugustine, R. P., Miller, R. J., Chang, K. J., and Cuatrecasas, P. (1978). An immunohistochemical and radioimmunological study of the distribution of [met5]- and [leu5]-enkephalin in the gastrointestinal tract. Neuroscience 3, 1187-1196. doi: 10.1016/0306-4522(78)90138-0

Liu, Q., Cescato, R., Dewi, D. A., Rivier, J., Reubi, J. C., and Schonbrunn, A. (2005). Receptor signaling and endocytosis are differentially regulated by somatostatin analogs. Mol. Pharmacol. 68, 90-101. doi: 10.1124/mol.105.011767

Liu, Q., Dewi, D. A., Liu, W., Bee, M. S., and Schonbrunn, A. (2008). Distinct phosphorylation sites in the SST2A somatostatin receptor control internalization, desensitization, and arrestin binding. Mol. Pharmacol. 73, 292-304. doi: 10.1124/mol.107.038570

Lloyd, K. C., Amirmoazzami, S., Friedik, F., Chew, P., and Walsh, J. H. (1997). Somatostatin inhibits gastrin release and acid secretion by activating sst 2 in dogs. Am. J. Physiol. 272, G1481-G1488.

Low, M. J. (2004). The somatostatin neuroendocrine system: physiology and clinical relevance in gastrointestinal and pancreatic disorders. Best Pract. Res. Clin. Endocrinol. Metab. 18, 607-622. doi: 10.1016/j.beem.2004.08.005

Maguma, H. T., Dewey, W. L., and Akbarali, H. I. (2012). Differences in the characteristics of tolerance to mu-opioid receptor agonists in the colon from wild type and beta-arrestin 2 knockout mice. Eur. J. Pharmacol. 685, 133-140. doi: 10.1016/j.ejphar.2012.04.001

Majeed, N. H., Silberring, J., and Przewlocki, R. (1987). The in vitro release of immunoreactive dynorphin and alpha-neoendorphin from the perfused rat duodenum. Life Sci. 41, 497-504. doi: 10.1016/0024-3205(87) 90227-X

Mansour, A., Hoversten, M. T., Taylor, L. P., Watson, S. J., and Akil, H. (1995). The cloned mu, delta and kappa receptors and their endogenous ligands: evidence for two opioid peptide recognition cores. Brain Res. 700, 89-98. doi: 10.1016/00068993(95)00928-J

Massotte, D. (2014). In vivo opioid receptor heteromerization: where do we stand? Br. J. Pharmacol. doi: 10.1111/bph.12702 [Epub ahead of print].

McIntosh, C. H., Bakich, V., Kwok, Y. N., and Brown, J. C. (1986). A comparison of the inhibitory effects of somatostatin-14, -25 , and -28 on motility of the guinea pig ileum. Can. J. Physiol. Pharmacol. 64, 303-306. doi: 10.1139/y86-048

McPherson, J., Rivero, G., Baptist, M., Llorente, J., Al-Sabah, S., Krasel, C., et al. (2010). mu-opioid receptors: correlation of agonist efficacy for signalling with ability to activate internalization. Mol. Pharmacol. 78, 756-766. doi: 10.1124/mol.110.066613

Melief, E. J., Miyatake, M., Bruchas, M. R., and Chavkin, C. (2010). Ligand-directed c-Jun N-terminal kinase activation disrupts opioid receptor signaling. Proc. Natl. Acad. Sci. U.S.A. 107, 11608-11613. doi: 10.1073/pnas.1000751107

Miller, R. J., and Hirning, L. D. (2010). "Opioid Peptides of The Gut," in Comprehensive Physiology. Hoboken, NJ: John Wiley \& Sons, Inc.

Mimoda, T., Kitamura, N., Hondo, E., and Yamada, J. (1998). Immunohistochemical colocalization of serotonin, substance P and Met-enkephalin-Arg6-Gly7-Leu8 in the endocrine cells of the ruminant duodenum. Anat. Histol. Embryol. 27, 65-69. doi: 10.1111/j.1439-0264.1998.tb00158.x

Mongardi Fantaguzzi, C., Thacker, M., Chiocchetti, R., and Furness, J. B. (2009). Identification of neuron types in the submucosal ganglia of the mouse ileum. Cell Tissue Res. 336, 179-189. doi: 10.1007/s00441-009-0773-2

Mor, A., Delfour, A., Amiche, M., Sagan, S., Nicolas, P., Grassi, J., et al. (1989). Dermorphin and related peptides in rat tissues. Neuropeptides 13, 51-57. doi: 10.1016/0143-4179(89)90021-8

Mor, A., Pradelles, P., Delfour, A., Montagne, J. J., Quintero, F. L., Conrath, M., et al. (1990). Evidence for Pro-dermorphin processing products in rat tissues. Biochem. Biophys. Res. Commun. 170, 30-38. doi: 10.1016/0006-291X(90)91236-L 
Murphy, R., and Turner, C. A. (1990). Isolation and microsequence analysis of guinea pig alpha-neo-endorphin. Peptides 11,65-68. doi: 10.1016/0196-9781(90) 90111-H

Nihei, K., and Iwanaga, T. (1985). Localization of Met-enkephalin-Arg6-Gly7-Leu8like immunoreactivity in the gastrointestinal tract of rat and pig. J. Histochem. Cytochem. 33, 1001-1006. doi: 10.1177/33.10.3900192

Noda, M., Teranishi, Y., Takahashi, H., Toyosato, M., Notake, M., Nakanishi, S., et al. (1982). Isolation and structural organization of the human preproenkephalin gene. Nature 297, 431-434. doi: 10.1038/297431a0

Nunn, C., Cervia, D., Langenegger, D., Tenaillon, L., Bouhelal, R., and Hoyer, D. (2004). Comparison of functional profiles at human recombinant somatostatin sst2 receptor: simultaneous determination of intracellular $\mathrm{Ca} 2+$ and luciferase expression in CHO-K1 cells. Br. J. Pharmacol. 142, 150-160. doi: 10.1038/sj.bjp.0705735

Orwoll, E. S., and Kendall, J. W. (1980). Beta-endorphin and adrenocorticotropin in extrapituitary sites: gastrointestinal tract. Endocrinology 107, 438-442. doi: 10.1210/endo-107-2-438

Papotti, M., Tarabra, E., Allia, E., Bozzalla-Cassione, F., Broglio, F., Deghenghi, R. et al. (2003). Presence of cortistatin in the human pancreas. J. Endocrinol. Invest 26, RC15-RC18. doi: 10.1007/BF03347348

Patel, Y. C., and Srikant, C. B. (1997). Somatostatin receptors. Trends Endocrinol. Metab. 8, 398-405. doi: 10.1016/S1043-2760(97)00168-9

Patierno, S., Zellalem, W., Ho, A., Parsons, C. G., Lloyd, K. C., Tonini, M., et al (2005). N-methyl-D-aspartate receptors mediate endogenous opioid release in enteric neurons after abdominal surgery. Gastroenterology 128, 2009-2019. doi: 10.1053/j.gastro.2005.03.042

Pfannkuche, H., Reiche, D., Firzlaff, U., Sann, H., and Schemann, M. (1998) Enkephalin-immunoreactive subpopulations in the myenteric plexus of the guinea-pig fundus project primarily to the muscle and not to the mucosa. Cell Tissue Res. 294, 45-55. doi: 10.1007/s004410051155

Polak, J. M., Bloom, S. R., Sullivan, S. N., Facer, P., and Pearse, A. G. (1977) Enkephalin-like immunoreactivity in the human gastrointestinal tract. Lancet 1, 972-974. doi: 10.1016/S0140-6736(77)92277-2

Poole, D. P., Pelayo, J. C., Scherrer, G., Evans, C. J., Kieffer, B. L., and Bunnett, N. W. (2011). Localization and regulation of fluorescently labeled delta opioid receptor, expressed in enteric neurons of mice. Gastroenterology 141, 982-991. doi: 10.1053/j.gastro.2011.05.042

Portbury, A. L., Pompolo, S., Furness, J. B., Stebbing, M. J., Kunze, W. A., Bornstein, J. C., et al. (1995). Cholinergic, somatostatin-immunoreactive interneurons in the guinea pig intestine: morphology, ultrastructure, connections and projections. J. Anat. 187, 303-321.

Pradayrol, L., Chayvialle, J. A., Carlquist, M., and Mutt, V. (1978). Isolation of a porcine intestinal peptide with C-terminal somatostatin. Biochem. Biophys. Res. Commun. 85, 701-708. doi: 10.1016/0006-291X(78)91218-4

Pradayrol, L., Jornvall, H., Mutt, V., and Ribet, A. (1980). N-terminally extended somatostatin: the primary structure of somatostatin-28. FEBS Lett. 109, 55-58. doi: 10.1016/0014-5793(80)81310-X

Puebla, L., Mouchantaf, R., Sasi, R., Khare, S., Bennett, H. P., James, S., et al (1999). Processing of rat preprocortistatin in mouse AtT-20 cells. J. Neurochem 73, 1273-1277. doi: 10.1046/j.1471-4159.1999.0731273.x

Rabbani, S. N., and Patel, Y. C. (1990). Peptides derived by processing of rat prosomatostatin near the amino-terminus: characterization, tissue distribution, and release. Endocrinology 126, 2054-2061. doi: 10.1210/endo-126-4-2054

Raehal, K. M., Schmid, C. L., Medvedev, I. O., Gainetdinov, R. R., Premont, R. T., and Bohn, L. M. (2009). Morphine-induced physiological and behavioral responses in mice lacking G protein-coupled receptor kinase 6. Drug Alcohol Depend. 104, 187-196. doi: 10.1016/j.drugalcdep.2009.04.011

Raehal, K. M., Walker, J. K., and Bohn, L. M. (2005). Morphine side effects in beta-arrestin 2 knockout mice. J. Pharmacol. Exp. Ther. 314, 1195-1201. doi: 10.1124/jpet.105.087254

Rajagopal, S., Bassoni, D. L., Campbell, J. J., Gerard, N. P., Gerard, C. and Wehrman, T. S. (2013). Biased agonism as a mechanism for differential signaling by chemokine receptors. J. Biol. Chem. 288, 35039-35048. doi: 10.1074/jbc.M113.479113

Ravazzola, M., Benoit, R., Ling, N., Guillemin, R., and Orci, L. (1983). Immunocytochemical localization of prosomatostatin fragments in maturing and mature secretory granules of pancreatic and gastrointestinal D cells. Proc. Natl. Acad. Sci. U.S.A. 80, 215-218. doi: 10.1073/pnas.80.1.215
Ravazzola, M., Benoit, R., Ling, N., and Orci, L. (1989). Prosomatostatin-derived antrin is present in gastric D cells and in portal blood. J. Clin. Invest. 83, 362-366. doi: 10.1172/JCI113892

Rivero, G., Llorente, J., Mcpherson, J., Cooke, A., Mundell, S. J., McArdle, C. A., et al. (2012). Endomorphin-2: a biased agonist at the mu-opioid receptor. Mol. Pharmacol. 82, 178-188. doi: 10.1124/mol.112.078659

Romero, A., Gonzalez-Cuello, A., Laorden, M. L., Campillo, A., Vasconcelos, N., Romero-Alejo, E., et al. (2012). Effects of surgery and/or remifentanil administration on the expression of pERK1/2, c-Fos and dynorphin in the dorsal root ganglia in mice. Naunyn Schmiedebergs Arch. Pharmacol. 385, 397-409. doi: 10.1007/s00210-011-0721-z

Ronai, A. Z., Kiraly, K., Szebeni, A., Szemenyei, E., Prohaszka, Z., Darula, Z., et al. (2009). Immunoreactive endomorphin 2 is generated extracellularly in rat isolated L4,5 dorsal root ganglia by DPP-IV. Regul. Pept. 157, 1-2. doi: 10.1016/j.regpep.2009.06.006

Rozenfeld, R., and Devi, L. A. (2007). Receptor heterodimerization leads to a switch in signaling: beta-arrestin2-mediated ERK activation by mu-delta opioid receptor heterodimers. FASEB J. 21, 2455-2465. doi: 10.1096/fj.06-7793com

Samson, W. K., Zhang, J. V., Avsian-Kretchmer, O., Cui, K., Yosten, G. L., Klein, C., et al. (2008). Neuronostatin encoded by the somatostatin gene regulates neuronal, cardiovascular, and metabolic functions. J. Biol. Chem. 283, 31949-31959. doi: 10.1074/jbc.M804784200

Sanger, G. J., and Tuladhar, B. R. (2004). The role of endogenous opioids in the control of gastrointestinal motility: predictions from in vitro modelling. Neurogastroenterol. Motil. 16(Suppl. 2), 38-45. doi: 10.1111/j.17433150.2004.00556.x

Schmidt, W. E., Mutt, V., Kratzin, H., Carlquist, M., Conlon, J. M., and Creutzfeldt, W. (1985). Isolation and characterization of proSS1-32, a peptide derived from the N-terminal region of porcine preprosomatostatin. FEBS Lett. 192, 141-146. doi: 10.1016/0014-5793(85)80060-0

Schultzberg, M., Hokfelt, T., Nilsson, G., Terenius, L., Rehfeld, J. F., Brown, M., et al. (1980). Distribution of peptide- and catecholamine-containing neurons in the gastro-intestinal tract of rat and guinea-pig: immunohistochemical studies with antisera to substance $\mathrm{P}$, vasoactive intestinal polypeptide, enkephalins, somatostatin, gastrin/cholecystokinin, neurotensin and dopamine beta-hydroxylase. Neuroscience 5，689-744. doi: 10.1016/0306-4522(80) 90166-9

Schulz, R., Wuster, M., Simantov, R., Snyder, S., and Herz, A. (1977). Electrically stimulated release of opiate-like material from the myenteric plexus of the guinea pig ileum. Eur. J. Pharmacol. 41, 347-348. doi: 10.1016/0014-2999(77)90331-4

Seal, A., Yamada, T., Debas, H., Hollinshead, J., Osadchey, B., Aponte, G., et al. (1982). Somatostatin-14 and -28: clearance and potency on gastric function in dogs. Am. J. Physiol. 243, G97-G102.

Shen, K. Z., and Surprenant, A. (1993). Somatostatin-mediated inhibitory postsynaptic potential in sympathetically denervated guinea-pig submucosal neurones. J. Physiol. 470, 619-635.

Song, Z. M., Brookes, S. J., Ramsay, G. A., and Costa, M. (1997). Characterization of myenteric interneurons with somatostatin immunoreactivity in the guineapig small intestine. Neuroscience 80, 907-923. doi: 10.1016/S0306-4522(96) 00605-7

Spampinato, S., Ferri, G. L., Candeletti, S., Romualdi, P., Cavicchini, E., Soimero, L., etal. (1988). Regional distribution of immunoreactive dynorphin A in the human gastrointestinal tract. Neuropeptides 11, 101-105. doi: 10.1016/0143-4179(88)90077-7

Spampinato, S., Speroni, E., Canossa, M., Sciarretta, G., Malaguti, P., and Ferri, S. (1992). Dynorphin B-like immunoreactivity in gastroduodenal biopsy specimens from gallstone patients. Regul. Pept. 41, 131-138. doi: 10.1016/01670115(92)90042-S

Steele, P. A., and Costa, M. (1990). Opioid-like immunoreactive neurons in secretomotor pathways of the guinea-pig ileum. Neuroscience 38, 771-786. doi: 10.1016/0306-4522(90)90070-K

Steele, P. A., Turner, C. A., and Murphy, R. (1989). Measurement and chromatographic characterization of prodynorphin-derived peptides in the guinea-pig ileum. Neuropeptides 13, 207-213. doi: 10.1016/0143-4179(89)90094-2

Sundler, F., Alumets, J., Ekman, R., Hakanson, R., and Van Wimersma Greidanus, T. B. (1981). Immunoreactive adrenocorticotropic hormone (ACTH) in porcine gut and pancreas: fact or artifact? J. Histochem. Cytochem. 29, 1328-1335. doi: $10.1177 / 29.11 .6172464$ 
Tang, J., Yang, H. Y., and Costa, E. (1982). Distribution of met5-enkephalin-Arg6Phe7 (MEAP) in various tissues of rats and guinea pigs. Life Sci. 31, 2303-2306. doi: 10.1016/0024-3205(82)90143-6

Terskiy, A., Wannemacher, K. M., Yadav, P. N., Tsai, M., Tian, B., and Howells, R. D. (2007). Search of the human proteome for endomorphin-1 and endomorphin-2 precursor proteins. Life Sci. 81, 1593-1601. doi: 10.1016/j.lfs.2007.09.025

Thompson, G. L., Kelly, E., Christopoulos, A., and Canals, M. (2014). Novel GPCR paradigms at the mu-opioid receptor. Br. J. Pharmacol. doi: 10.1111/bph.12600 [Epub ahead of print].

Traub, R. J., Hutchcroft, K., and Gebhart, G. F. (1999). The peptide content of colonic afferents decreases following colonic inflammation. Peptides 20, 267-273. doi: 10.1016/S0196-9781(98)00157-0

Valdez-Morales, E., Guerrero-Alba, R., Ochoa-Cortes, F., Benson, J., Spreadbury, I., Hurlbut, D., et al. (2013). Release of endogenous opioids during a chronic IBD model suppresses the excitability of colonic DRG neurons. Neurogastroenterol. Motil. 25, 39.e4-46.e4. doi: 10.1111/nmo.12008

Van Op den Bosch, J., Adriaensen, D., Van Nassauw, L., and Timmermans, J. P. (2009). The role(s) of somatostatin, structurally related peptides and somatostatin receptors in the gastrointestinal tract: a review. Regul. Pept. 156, 1-8. doi: 10.1016/j.regpep.2009.04.003

Verma-Gandhu, M., Bercik, P., Motomura, Y., Verdu, E. F., Khan, W. I., Blennerhassett, P. A., et al. (2006). CD4+ T-cell modulation of visceral nociception in mice. Gastroenterology 130, 1721-1728. doi: 10.1053/j.gastro.2006.01.045

Verma-Gandhu, M., Verdu, E. F., Cohen-Lyons, D., and Collins, S. M. (2007). Lymphocyte-mediated regulation of beta-endorphin in the myenteric plexus. Am. J. Physiol. Gastrointest. Liver Physiol. 292, G344-G348. doi: 10.1152/ajpgi.00318.2006

Vincent, S. R., Dalsgaard, C. J., Schultzberg, M., Hokfelt, T., Christensson, I., and Terenius, L. (1984). Dynorphin-immunoreactive neurons in the autonomic nervous system. Neuroscience 11, 973-987. doi: 10.1016/0306-4522(84)90208-2

Waldhoer, M., Bartlett, S. E., and Whistler, J. L. (2004). Opioid receptors. Annu. Rev. Biochem. 73, 953-990. doi: 10.1146/annurev.biochem.73.011303.073940

Waldhoer, M., Fong, J., Jones, R. M., Lunzer, M. M., Sharma, S. K., Kostenis, E., et al. (2005). A heterodimer-selective agonist shows in vivo relevance of $\mathrm{G}$ protein-coupled receptor dimers. Proc. Natl. Acad. Sci. U.S.A. 102, 9050-9055. doi: $10.1073 /$ pnas.0501112102

Walsh, J. H. (1988). Peptides as regulators of gastric acid secretion. Annu. Rev. Physiol. 50, 41-63. doi: 10.1146/annurev.ph.50.030188.000353

Wang, Y. N., and Lindberg, I. (1986). Distribution and characterization of the opioid octapeptide met5-enkephalin-arg6-gly7-leu8 in the gastrointestinal tract of the rat. Cell Tissue Res. 244, 77-85. doi: 10.1007/BF00218384

Weinstock, J. V., and Elliott, D. (2000). The somatostatin immunoregulatory circuit present at sites of chronic inflammation. Eur. J. Endocrinol. 143(Suppl. 1), S15S19. doi: 10.1530/eje.0.143S015

Wolter, H. J. (1985a). Colocalization of dynorphin-A(1-17) and dynorphin-A(1-8) within some perikarya of rat duodenum: immunohistochemical evidence for the presence of two separate dynorphinergic systems. Biochem. Biophys. Res. Commun. 130, 774-780. doi: 10.1016/0006-291X(85)90483-8
Wolter, H. J. (1985b). Ultrastructural evidence for beta-endorphin-like immunoreactivity in the nervous system of the rat duodenum. Brain Res. 334, 194-199. doi: 10.1016/0006-8993(85)90588-8

Wolter, H. J. (1986). Identification of the tridecapeptide dynorphin B (rimorphin) within perikarya of rat duodenum. Life Sci. 39, 727-730. doi: 10.1016/00243205(86)90020-2

Wood, J. D., and Galligan, J. J. (2004). Function of opioids in the enteric nervous system. Neurogastroenterol. Motil. 16(Suppl. 2), 17-28. doi: 10.1111/j.17433150.2004.00554.x

Yakovleva, T., Bazov, I., Cebers, G., Marinova, Z., Hara, Y., Ahmed, A., et al. (2006). Prodynorphin storage and processing in axon terminals and dendrites. FASEB J. 20, 2124-2126. doi: 10.1096/fj.06-6174fje

Yuferov, V. P., Culpepper-Morgan, J. A., Laforge, K. S., Ho, A., and Kreek, M. J. (1998) Regional quantitation of preprodynorphin $\mathrm{mRNA}$ in guinea pig gastrointestinal tract. Neurochem. Res. 23, 505-511. doi: 10.1023/A:1022426400545

Zadina, J. E., Hackler, L., Ge, L. J., and Kastin, A. J. (1997). A potent and selective endogenous agonist for the mu-opiate receptor. Nature 386, 499-502. doi: $10.1038 / 386499 \mathrm{a} 0$

Zamir, N., Weber, E., Palkovits, M., and Brownstein, M. (1984). Differential processing of prodynorphin and proenkephalin in specific regions of the rat brain. Proc. Natl. Acad. Sci. U.S.A. 81, 6886-6889. doi: 10.1073/pnas.81.21.6886

Zhao, P., Canals, M., Murphy, J. E., Klingler, D., Eriksson, E. M., Pelayo, J. C., et al. (2013). Agonist-biased trafficking of somatostatin receptor 2A in enteric neurons. J. Biol. Chem. 288, 25689-25700. doi: 10.1074/jbc.M113.496414

Zingg, H. H., and Patel, Y. C. (1983). Processing of somatostatin-28 to somatostatin14 by rat hypothalamic synaptosomal membranes. Life Sci. 33, 1241-1247. doi: 10.1016/0024-3205(83)90004-8

Zweemer, A. J., Toraskar, J., Heitman, L. H., and IJzerman, A. P. (2014). Bias in chemokine receptor signalling. Trends Immunol. 35, 243-252. doi 10.1016/j.it.2014.02.004

Conflict of Interest Statement: The authors declare that the research was conducted in the absence of any commercial or financial relationships that could be construed as a potential conflict of interest.

Received: 29 September 2014; accepted: 12 November 2014; published online: 28 November 2014.

Citation: Thompson GL, Canals $M$ and Poole DP (2014) Biological redundancy of endogenous GPCR ligands in the gut and the potential for endogenous functional selectivity. Front. Pharmacol. 5:262. doi: 10.3389/fphar.2014.00262

This article was submitted to Neuropharmacology, a section of the journal Frontiers in Pharmacology.

Copyright (c) 2014 Thompson, Canals and Poole. This is an open-access article distributed under the terms of the Creative Commons Attribution License (CC BY). The use, distribution or reproduction in other forums is permitted, provided the original author(s) or licensor are credited and that the original publication in this journal is cited, in accordance with accepted academic practice. No use, distribution or reproduction is permitted which does not comply with these terms. 